\title{
CONTROVÉRSIAS E DESAFIOS METODOLÓGICOS E POLÍTICOS DA CLASSIFICAÇÃO RACIAL NA BIOMEDICINA
}

\author{
Tatiane Pereira Muniz \\ (PPGAS-UFRGS/IFBA - taty_rp@yahoo.com.br)
}

\begin{abstract}
RESUMO:
A Biologia e as ciências da vida tem refutado a raça enquanto categoria biológica para classificar seres humanos desde a declaração das raças da UNESCO que data dos anos 1950. Entretanto, categorias raciais continuam a ser utilizadas na prática médica, especialmente na investigação genômica. Nos primeiros estudos realizados depois do Projeto Genoma, no início do século XXI, a tecnologia genética tem se orientado principalmente para estudos de ancestralidade genômica, considerando que existem polimorfismos que distinguem diferentes populações, que estes polimorfismos são importantes para predizer certas condições genéticas em saúde e podem justificar a segregação os seres humanos em grupos discretos. De acordo com a genética médica, alguns destes polimorfismos expõem os indivíduos a especificidades biológicas e fisiológicas que devem ser consideradas no diagnóstico e no tratamento de saúde na perspectiva de prevenir disparidades em saúde. As controvérsias emergem quando discursos em torno de disparidades na biologia se conectam com as desigualdades em saúde como efeito do racismo, desafiando pesquisadores da área médica, profissionais de saúde, gestores de políticas públicas e os movimentos sociais a desnaturalizarem tais diferenças em suas práticas ao mesmo tempo em que contribuem para materializá-las. A partir do trabalho etnográfico realizado entre geneticistas, profissionais de saúde, gestores de saúde e movimentos sociais no sul do Brasil, este artigo traz algumas reflexões sobre as complexidades e controvérsias acerca dos processos científicos e políticos de classificação racial.
\end{abstract}

Palavras-chave: Raça, Genética, Saúde

\begin{abstract}
:
Biology and the Life Sciences have refused race as a biological category for humans since the UNESCO declaration about race in the fifty's. Still, racial categories continue to be used in medical practices and especially in medical genomic research. In the first studies conducted after The Genome Project in the beginning of the $21^{\text {st }}$ Century, genetics technology mainly targeted genomic ancestry studies taking for granted that there are polymorphisms that distinguish different populations, that these are important to predict certain genetic health conditions and can justify the segregation human beings into discrete groups. According to medical genetics some of these polymorphisms expose an individual to biological and physiological specificities that should be considered in diagnoses and health treatments in order to prevent health disparities. The controversies emerge when discourses around biological health disparities interwoven with health inequalities as the effect of racism challenging medical researchers, public policies makers, and social movements to denaturalizing such differences in their practices while materializing them. Through an ethnographic work conducted among geneticists, health professionals, public policies makers and black social movements in south of Brazil, this article draws attention to such complexities and controversies around process of scientific and political racial classification.
\end{abstract}

KEY WORDS: Race, Genetics, Health 
A partir da etnografia em laboratórios de genética médica, e em outros espaços nos quais se produzem saberes sobre o corpo e suas especificidades raciais, no Sul do Brasil, entre os anos de 2017 e 2018, tenho buscado compreender, ao longo da investigação do doutorado, como diferentes versões de raça se materializam em práticas e narrativas institucionais, particularmente no que concerne ao campo da saúde. Este interesse surgiu a partir das repercussões em torno das promessas do Projeto Genoma Humano, no início dos anos 2000, que alimentaram o imaginário social com expectativas em torno da genética preditiva e intervenção precoce para prevenção e tratamento de doenças.

Deste modo minha trajetória em campo começou com a etnografia das práticas dos geneticistas (aulas, reuniões de grupo de pesquisa, trabalho de bancada nos laboratórios, cursos de extensão) além da realização de entrevistas com profissionais da área biomédica, mais tarde extrapolando para a interlocução com profissionais de outras instâncias institucionais voltadas para a intervenção em saúde, entre os quais categorias raciais são mobilizadas com vistas à reivindicação e elaboração de políticas públicas (grupo de trabalhos de instâncias municipais e federais, cursos de formação de promotores em saúde da população negra, entrevistas com representantes dos movimentos sociais).

Minha atenção se voltou, mais detidamente, para a relação entre genética e a classificação racial entre seres humanos quando um jornal de circulação nacional divulgou a notícia de que os indígenas "podem agora dizer com mais autoridade que são realmente índios" (Folha de São Paulo, 08/09/2007), uma vez que já seria possível fazer testes de ancestralidade genômica para atestar o pertencimento étnico. Na ocasião eu trabalhava com etnologia indígena no Programa de Pesquisas sobre Povos Indígenas do Nordeste Brasileiro, na Universidade Federal da Bahia, e aquela notícia inquietou-me, pois eu vislumbrava o seu potencial perturbador para temas caros à antropologia como parentesco, ancestralidade e identidade étnica que, no caso indígena, estavam intimamente ligados à luta pelo território.

Àquela altura, a busca da materialidade genética para a comprovação da identidade étnica parecia ir de encontro aos debates clássicos da antropologia no tocante à identidade, uma vez que se preconiza a autodeterminação dos povos, prevista pelo direito internacional público, e o caráter situacional (POUTIGNAT e STREIFF-FENART,1998; VILLAR, 2004) e imaginado (ANDERSON, 2008) das identidades. Isto significa dizer que o tratamento 


\section{Nanduty}

ISSN:2317-8590

conferido pela antropologia ao tema da identidade a toma como algo que não é fixo ou determinado, mas permanentemente negociado e atualizado no confronto com a alteridade.

Aventar a possibilidade de localizar o pertencimento identitário em marcadores genéticos relacionados a uma ancestralidade genômica, que remete a velhas categorias de classificação racial, parecia sugerir a fixação de grupos humanos em categorias estanques que não coincide com uma suposta realidade empírica ou ontológica, uma vez que as fronteiras da classificação tanto biológica quanto étnica são constitutivamente borradas. Isto é, a dinâmica dos fluxos migratórios entre populações, dos arranjos sociais e da distribuição gênica subvertem o ordenamento e coordenação de grupos em categorias que façam conciliar o entrecruzamento cultural e genético em contextos multiculturais e miscigenados como é o caso do Brasil.

A utilização dos estudos genéticos para rastreamento da ancestralidade e sua relação com a identidade étnica era apenas uma dentre as múltiplas finalidades da investigação do genoma humano. Paralelamente ao estudo sobre a relação entre genética e identidade, comecei a me interessar pelo modo como os estudos de ancestralidade genômica estavam sendo utilizados com outros objetivos, tanto aqueles mais lúdicos e comerciais como o do Genographic Project e do 23 and $m e^{1}$, quanto aqueles ligados à área médica.

Meu interesse de pesquisa sobre o modo como a genética lida com categorias de classificação racial aliado a minha trajetória de estudo da temática das relações étnicas e raciais foram-me conduzindo a explorar o campo da saúde, tendo em vista que fui descobrindo, ao longo da pesquisa exploratória das publicações científicas em genética, o crescente número de investigações (Plataformas NCBI e PubMed ${ }^{2}$ ) que correlacionavam estudos de ancestralidade genômica, a partir de grupos racialmente classificados, a suscetibilidades e predisposições a doenças. Neste sentido, minha aproximação dos geneticistas se deu na perspectiva de compreender como se considerava a pertinência da raça nas questões da saúde ao mesmo tempo em que a dimensão biológica desta categoria era rechaçada. Era igualmente curioso pensar na manutenção de categorias raciais para classificar

\footnotetext{
${ }^{1}$ Projetos que trabalham com rastreamento de ancestralidade genômica e permitem localizar a origem geográfica dos ancestrais de um indivíduo a partir da análise do DNA. O interessado pode encomendar um kit para coleta de saliva e enviar para a análise, podendo obter informações diversas sobre suas características genéticas e de sua família. Ver: <https://genographic.nationalgeographic.com> e https://www.23andme.com/en-int/.

${ }^{2}$ Ver https://www.ncbi.nlm.nih.gov e https://www.ncbi.nlm.nih.gov/pubmed
} 


\section{Nanduty}

ISSN:2317-8590

populações, quando investigações no campo da genômica estão cada vez mais direcionadas para uma medicina personalizada.

Desde a leitura exploratória de artigos científicos da área médica já me instigava a diversidade de categorias com as quais as diferentes populações consideradas nos estudos são classificadas, algumas vezes remetendo à origem geográfica (africano, europeu, asiático, nativo-americanos), etnia ou nacionalidade, outras, a categorias com maior conotação racial, como caucasoide, negro, amarelo. O modo controverso do emprego dessas categorias na divulgação dos trabalhos científicos despertou ainda mais minha curiosidade em compreender os métodos empregados pelos geneticistas para estabilizar, em suas práticas de investigação, categorias tão fugidias, especialmente porque o resultado destes estudos subsidiam a criação de parâmetros para o diagnóstico e intervenção em saúde.

O acirrado debate entre geneticistas e antropólogos no início dos anos 2000 (PENA e BORTOLINI, 2001; PENA, 2005; PENA, 2007; KENT, 2012; KENT e SANTOS, 2012; BORTOLINI, 2012) bem como a realização de trabalho etnográfico entre aqueles profissionais, mais recentemente, apontou, entretanto, que a possibilidade de a genética determinar a identidade de grupos também tem sido rechaçada por este campo, pelo menos no Brasil, e, especialmente no que tange à finalidade de atestar o pertencimento identitário com finalidades de acesso a políticas públicas territoriais e educacionais. O início dos anos 2000 foi também emblemático dessas disputas tendo em vista que era o contexto no qual se começava a implementação das ações afirmativas de recorte racial para acesso às universidades públicas brasileiras e, dados os dilemas de classificação racial com esta finalidade, alguns geneticistas se posicionaram contrários à possibilidade de a genética definir quem seria elegível para as cotas (PENA e BORTOLINI, 2004).

O caminho argumentativo dos geneticistas que têm se posicionado contra o papel da genética em atestar identidades via testes de ancestralidade baseia-se na afirmação de que não há sentido em se falar de raças para seres humanos e que raça não existe. Eles também recorrem ao argumento da miscigenação para afirmar que não existem fronteiras definidas para a classificação racial. A controvérsia incide, entretanto, no fato de que este tipo de argumento é verificado quando a classificação racial é aventada para o que os geneticistas denominam "finalidades políticas", enquanto as classificações que remetem a noções de raça continuam sendo empregadas com finalidades metodológicas, que no fim das contas expressam decisões e respostas políticas às demandas da comunidade científica e de esferas 


\section{Nanduty}

ISSN:2317-8590

do estado responsáveis pela elaboração de políticas de saúde com recorte racial. Enfim, noções de raça aparecem de modo intermitente no discurso dos cientistas, mas se materializam, cotidianamente, em suas práticas. Empregam-se termos substitutos, mas o modo como os estudos são conduzidos e publicados não prescindem de categorias raciais.

Com estas observações não quero aqui assumir uma postura denuncista acerca das estratégias de classificação destes profissionais, mas destacar como tais estratégias precisam lidar com demandas e desafios para tratar de raça, pois por mais que, à primeira vista, haja um consenso de que raça não faz sentido para a genética, estudos que correlacionam ancestralidade genômica com vulnerabilidades raciais em saúde tem sido utilizados para subsidiar políticas públicas com recorte racial (Corrêa et al., 2010; OLIVEIRA, 2003; ABESANDES et al., 2010), na medida que profissionais da área médica têm sido convocados a falar de especificidades raciais em saúde, grupos gestores da área da saúde precisam dar conta de grupos de trabalhos em secretarias e ministérios para responder demandas de políticas públicas com recorte racial, etc.

Observa-se, portanto, que, se por um lado se nega a possibilidade de empregar a raça, com um sentido biológico, com finalidades políticas - no pleito de acesso às políticas identitárias na educação e em questões territoriais -, por outro, a raça enquanto categoria que teria importância médica é acionada e legitimada por profissionais que inicialmente a rechaçam, subsidiando o investimento em pesquisas da indústria farmacêutica no país, e a elaboração de políticas públicas com recorte racial na área de saúde.

Desse modo, quero argumentar que a despeito do consenso em torno da existência ou não de raças humanas, seja entre os geneticistas e demais profissionais de saúde com os quais tenho conversado, seja entre antropólogos e profissionais que trabalham com elaboração e gestão de políticas públicas com recorte racial, existe uma "infraestrutura de racialização" (LEE, 2005) que demanda diferentes engajamentos em torno da temática racial, nos quais algum processo de classificação é levado a cabo. Isto é, viver em uma sociedade racializada nos coloca cotidianamente diante de demandas institucionais e burocráticas que desafiam política e metodologicamente aqueles que precisam responder a estas demandas, de modo aparentemente imediato, especialmente quando vinculados a qualquer esfera do saber-poder. Quando digo "aparentemente imediatos" refiro-me ao fato de que um conjunto de mediações estão em jogo, subsidiando decisões pautadas na raça. Esta se materializa, aqui e ali, em bancos de perfis genômicos, quando classificados em mais ou menos miscigenados, em fichas 


\section{Nanduty}

ISSN:2317-8590

cadastrais no serviço de saúde, quando se preenche ou não o quesito raça-cor, nos prontuários médicos, nas taxas de referências de exames laboratoriais, no tipo de medicamento prescrito para indivíduos pertencentes aos chamados diferentes grupos populacionais, etc.

Estas controvérsias em torno da existência ou não de raça, que se materializa e se desmaterializa em circunstâncias muito particulares, têm me levado a pensá-la no bojo de uma disputa de narrativas que a coloca e recoloca em práticas de saber-poder (FOUCAULT, 1975; 1977; 1972) nas quais apenas alguns atores teriam a autoridade de decidir quando é pertinente ou não considerar sua existência. Desse modo, mais do que uma categoria ontológica, a raça é sempre atualizada como uma categoria objeto de decisão. Isto tem sido evidenciado de modo recorrente na interlocução com geneticistas, para os quais operacionalizar raça em suas investigações coloca um constrangimento que vai desde preocupações sobre responsabilidade ética e política de colocar esta categoria em evidência (estou sendo racista falando/considerando ou silenciando sobre a raça?), até dificuldades sobre como lidar com processos de classificação que, apesar de reivindicados como recursos estritamente metodológicos, não deixam de desafiá-los em suas práticas.

Tenho pensado sobre tais constrangimentos como fruto de um processo histórico de silenciamento sobre a raça, no contexto brasileiro, especialmente a partir do mito da democracia racial que alimenta o imaginário social, até o presente, com ênfase no caráter miscigenado da população e a suposta inexistência do racismo que lhe seria correlata. $\mathrm{O}$ entrecruzamento racial, apesar de ser reconhecidamente uma violenta estratégia biopolítica de branqueamento da população brasileira é tomado como argumento para a inexistência do racismo, já que o país tem sua imagem associada à cordialidade entre as raças (SHWARCS, $1993 ;$ 1996).

A reiteração da miscigenação como um traço característico da população brasileira impõe alguns desafios aos geneticistas, primeiro porque se sentem exigidos pela comunidade científica internacional para um maior rigor na explicitação dos marcadores raciais empregados em suas investigações e, segundo, pela dificuldade de garantir este rigor na classificação de uma população tão miscigenada.

A pesquisa tem evidenciado, portanto que a categoria "miscigenação" tem sido acionada pelo menos de quatro maneiras: 1) realidade ontológica que confere especificidade à população brasileira, 2) capital científico que atrai o interesse da comunidade científica internacional e da indústria farmacêutica para a realização de pesquisas no Brasil, 3) fator de 


\section{Nanduty}

ISSN:2317-8590

confusão nas práticas de investigação, já que dificulta a classificação das populações com fronteiras menos borradas e 4) dispositivo de deslegitimação de pleitos de políticas públicas com recorte racial devido à dificuldade de separar as populações em grupos discretos.

Além de uma espécie de dificuldade operacional em lidar com as classificações raciais e os riscos éticos e políticos de lidar com um tema controverso, os constrangimentos de falar de raça seja pelo cientista ou pela sociedade, de modo mais amplo, diz respeito ao tabu que se tornou falar deste tema a partir das interdições colocadas pelo UNESCO, a partir de 1950, com a Declaração das Raças elaborada após as consequências do holocausto nazista e seu viés racista e eugênico.

Conforme a declaração,

Do ponto de vista biológico, a espécie Homo sapiens compõe-se de um certo número de grupos que diferem uns dos outros pela freqüência [sic.] de um ou de vários gens [sic.] particulares. Mas esses mesmos gens aos quais devem imputar-se as diferenças hereditárias existentes entre os homens são sempre em pequeno número considerando o conjunto da constituição genética do homem e a grande quantidade de gens comuns a todos os seres humanos, qualquer que seja o grupo a que pertencem. Resumindo, as semelhanças entre os homens são muito maiores do que as diferenças (UNESCO, 1950).

Considerando o modo como a diversidade biológica se manifesta em diferentes concentrações referentes à frequência e distribuição de genes ou de caracteres físicos, designadas pelo termo raça, a declaração da UNESCO destaca o caráter temporal e circunstancial destas variações entre diferentes populações, considerando o caráter arbitrário como estas diferenças são significadas socialmente. Existiria, portanto, para a UNESCO, uma noção de raça ontológica separada da forma como esta é interpretada socialmente, e que subsidia o argumento dos profissionais da biologia e das ciências da vida.

Em resumo, a palavra "raça" designa um grupo ou uma população caracterizada por certas concentrações, relativas quanto à frequência [sic] e à distribuição, de gens ou de caracteres físicos que, no decorrer dos tempos, aparecem, variam e muitas vezes até desaparecem sob a influência de fatores de isolamento geográficos ou culturais. Cada grupo reflete de modo diferente as manifestações variáveis desses caracteres em populações diferentes. Sendo as nossas observações largamente afetadas pelos nossos preconceitos, somos levados a interpretar arbitrária e inexatamente toda variabilidade que se produz num grupo dado como uma diferença fundamental que o separa dos outros de modo decisivo (UNESCO, 1950). 


\section{Nanduty}

ISSN:2317-8590

A hesitação inicial dos meus interlocutores sobre o emprego da categoria raça em seus trabalhos estava, em grande medida, associada à ratificação do que está colocado pela declaração, expondo que há variações em termos populacionais mas que estas não depõem contra a humanidade, nem justifica a hierarquização das diferentes populações. Entretanto interditar a raça do discurso, além de não resolver os problemas das desigualdades assentadas no racismo não impede que as diferenças continuem sendo reproduzidas e reiteradas, e, a raça, reificada, na medida em que os parâmetros para a classificação das populações ainda são carregados de conotações raciais.

Há uma divisão entre alguns geneticistas que, por um lado, são enfáticos ao afirmarem que aquilo que socialmente reconhecemos por raça (aspectos fenotípicos) tem pouca correlação com os genótipos (PENA, 2004; 2005), já que poucos genes estariam implicados na expressão desses traços; e por outro, aqueles empenhados no desenvolvimento de bancos de perfis genéticos ${ }^{3}$, com a catalogação de populações miscigenadas como as latinoamericanas, insistem na importância médica de considerar o fator racial em suas investigações.

A molecularização de procedimentos tem sido algo cada vez mais recorrente no campo da saúde, com o advento da genômica, e tem repercutido na forma como representamos o corpo. Conforme observam Marko Monteiro e Ricardo Vêncio (2012), investigações recentes da prática científica vêm analisando o conceito de molecularização da vida e do corpo a partir de múltiplas perspectivas, que apontam para uma importante mudança nas formas de classificação científica: "antes baseadas na fisiologia, nomeando e dando sentido ao corpo a partir de sua aparência externa e das suas macro estruturas, [hoje] essas classificações são cada vez mais baseadas em características moleculares ou genéticas" (MONTEIRO e VÊNCIO, 2012: 151).

De acordo com os autores, formas moleculares de representação podem ser descritas para além de sua relação com a biologia molecular (o DNA, o RNA e as proteínas), uma vez que ocorre um deslocamento das bases de classificação "da fisiologia para a informação, do visual para o numérico e do diagnóstico para a manipulação". Assim, na perspectiva dessas emergentes formas de classificação, "representar" não significa apenas definir ou descrever

\footnotetext{
${ }^{3}$ Ver, por exemplo, a iniciativa de alguns geneticistas na criação da Brasilian Iniciative on Precision Medicine. Disponível em: https://bipmed.org.
} 


\section{Nanduty}

ISSN:2317-8590

aspectos do corpo, mas implica também em formas de manipular e interferir neste mesmo corpo e, ao mesmo tempo, impactar nas compreensões sobre saúde e doença.

Paul Gilroy (2007) enxerga nestas novas possibilidades de escrutínio e classificação do corpo um processo de superação da raciologia; uma vez que "o corpo torna-se penetrável de todo e é reconfigurado como epifenômeno transitório da informação codificada e invisível, aquela estética, aquele regime de poder pautados na superfície estão terminados de modo irrecuperável". (GILROY, 2007: 70). Assim, o autor vislumbra a possibilidade de uma abordagem antirracialista do corpo na medida em que

hoje a pele não é mais privilegiada como o limiar da identidade ou da particularidade. Há boas razões para supor que a linha entre o interno e o externo passe em outro lugar. As fronteiras da raça ultrapassam o limiar da pele. Elas são celulares e moleculares, e não dermais. Se a "raça" puder resistir, ela assumirá uma nova forma, alienada das escalas respectivamente associadas com a anatomia política e epidermização. (GILROY, 2007:70).

Entretanto não é este o caminho que as pesquisas genômicas têm apontado uma vez que a sofisticação da biologia molecular tem levado as classificações raciais para estruturas cada vez mais ínfimas, como as regiões cromossômicas, para buscar a materialidade de variações que justifiquem exploração de diferenças que teriam importância médica, sem abrir mão da triagem de indivíduos por critérios fenótipos que passam pela cor da pele.

Distinguindo os estudos de ancestralidade genômica global, mais comumente realizados no Brasil, que seriam aqueles que buscam o grau de miscigenação da população brasileira a partir de três grandes grupos de populações parentais (africana, nativo-americana e europeia), uma médica geneticista envolvida com a criação de um banco de perfil genômico brasileiro explicou-me sobre a importância médica de considerar a classificação racial dos indivíduos em escala ainda menor:

T: E qual a importância dessa ancestralidade local, pensando em termos, assim, de tratamento de doenças? O uso clínico dessas informações...

G: Tá, anham, existe por exemplo... porque você pode ter, ter numa determinada região do cromossomo, um gene, que você sabe que na população africana predispõe pra uma determinada doença, só que aí você pega o indivíduo que é $90 \%$ europeu, mas naquele pedacinho ele é africano, você fala "não, esse indivíduo é europeu, ele não tem risco nenhum de desenvolver essa doença", só que naquele pedacinho que é o que interessa, ele é africano (risos) e aí ele tem, entendeu? Então na verdade, a ancestralidade global, ela é uma coisa, que não... então é mais uma curiosidade, digamos assim; do ponto de vista médico, a ancestralidade global não tem significado 


\section{Nanduty}

ISSN:2317-8590

nenhum, o que importa é a ancestralidade local, é... na.. na... naquele local que tem um gene que predispõe pra uma doença, eu quero saber aquele pedacinho qual que é a ancestralidade.

Conforme explicava uma professora em uma aula sobre fundamentos de genômica para a biomedicina que tive oportunidade de assistir como ouvinte na universidade, logo quando iniciava meu trabalho de campo e buscava me familiarizar com a gramática da genômica, "não é possível fazer pesquisa genômica sem a noção de grupo populacional".

No decorrer dos encontros, assim como já tinha verificado em artigos científicos e conversas com profissionais da área, tais classificações, apesar de referidas em termos populacionais, sempre resvalavam para categorias raciais (como caucasoide, negroide) ou étnicas (judeus askenazi), ou ainda origens continentais (africanos, europeus, asiáticos) e, apesar das controvérsias e ambiguidades, a genética médica tem conduzido estudos que correlacionam ancestralidade genômica com suscetibilidades e predisposições a doenças, como nos estudos que buscam especificidades do câncer de mama em diferentes populações (MONTEIRO e VÊNCIO, 2012; CORRÊA et al., 2010), ou diferenças na evolução dos casos de HIV pra Aids (ABE-SANDES, 2010), entre diferentes grupos etnicamente classificados.

Além da variação nos critérios de classificação, outra controvérsia metodológica nas investigações médicas diz respeito à triagem dos pacientes. Logo quando comecei a fazer uma pesquisa exploratória sobre o tema, em 2009, tive a oportunidade de conversar com uma oncologista na cidade de Salvador, envolvida em um projeto de pesquisa que buscava relacionar a especificidade do câncer de mama em diferentes regiões do Brasil com a ancestralidade genômica. Tratava-se de um consórcio de pesquisa no qual haveria coleta de material biológico em diferentes regiões do país para serem enviadas para análise em um laboratório na Inglaterra. Apesar de o projeto trazer no seu título menção ao termo "étnicoracial" e prever a coleta em diferentes regiões, considerando a maior presença fenotípica de brancos, negros e indígenas em São Paulo, Salvador e Manaus, respectivamente, a médica negava que pesquisa considerava a raça ou que esta categoria fizesse sentido para a genética.

Essa distribuição geográfica da triagem me pareceu problemática, de imediato, já que imaginei que os supostos da pesquisa desconsideravam a presença destas populações em outros estados, ou, a possibilidade de encontrar as três populações parentais (africana, europeia e nativo-americana, como tem sido consideradas nos estudos de genética populacional) em um mesmo estado. Quando questionei os critérios para a seleção das 


\section{Nanduty}

ISSN:2317-8590

cidades privilegiadas pelo estudo - por julgar que reificava e reduzia a presença dessas populações a tais regiões - a justificativa para tal distribuição estava no fato de haver maior presença dos pacientes com os perfis desejados sendo atendidos nos hospitais públicos, o que facilitaria a coleta. Assim, o material biológico de pessoas com ancestralidade europeia seria coletado em São Paulo, de pessoas com ancestralidade indígena, em Manaus e, de pessoas com ancestralidade africana, em Salvador.

\section{DESAFIOS INSTITUCIONAIS E POLÍTICOS DA CLASSIFICAÇÃO RACIAL}

Demonstradas, neste breve panorama, as controvérsias metodológicas do emprego de categorias raciais das investigações genéticas na era da genômica, e as disputas acerca da pertinência da raça nas investigações e práticas biomédicas, trago a seguir algumas das questões que orientaram minha pesquisa: quais são as "condições de possibilidade" que ensejam a reemergência da raça no campo da biomedicina, particularmente no campo da genética médica? Qual o sentido do recorte populacional, com conotações raciais, nestas investigações em um contexto que acena, cada vez, mais para uma medicina personalizada?

Conforme Michel Foucault (1976) as classificações humanas em termos raciais sempre pautaram as estratégias biopolíticas de controle populacional. A própria história da medicina social no Brasil esteve pautada em intervenções eugênicas e higienistas, em que a regulação dos corpos se deu de modo racializado. Políticas de controle reprodutivo estiveram, no final do século XIX e, ao longo das primeiras décadas do século XX, comprometidas com o branqueamento da população estando, portanto investida de um caráter eugênico.

Dada a herança do racismo científico no pensamento científico brasileiro, não é por acaso que a raça é rechaçada quando sua correlação com a genética emerge nos debates sobre classificação de grupos populacionais, seja para finalidades médicas ou definição de elegibilidade para políticas públicas de recorte racial, na contemporaneidade.

A possibilidade de manipulação gênica que permeia o imaginário social, bem como as preocupações filosóficas acerca do futuro da natureza humana são assombradas pela possibilidade de uma eugenia liberal (HABEMANS, 2001), com a potencial exploração econômica do genoma e novas intervenções eugênicas, mediadas pela biotecnologia. Este tipo de intervenção está muito mais próxima da vida real, bastando para tanto consultar alguns 


\section{Nanduty}

ISSN:2317-8590

estudos sobre "design babies" ou sobre os critérios de seleção de gametas para fertilização in vitro, no Brasil (COSTA, 2012).

Apesar de a literatura atenta ao emprego da categoria raça na era da genômica tratá-la nos termos de uma reemergência, tendo a argumentar que a raça sempre esteve subjacente nos processos de classificação no Brasil, constituindo categoria de análise fundamental no pensamento social brasileiro. Ainda que o estudo das particularidades e desigualdades resvalassem, aqui e ali, para noções como cultura e classe social, a raça sempre esteve subjacente à distribuição de posições dos sujeitos na sociedade.

Nesse sentido a chamada reemergência da raça na era da genômica seria apenas mais um versão por meio da qual raça se materializa e, alinhando-me ao que defende Amade M’Charek (2010, 2013, 2014), o desafio é desnaturalizá-la sem desmaterializá-la, se quisermos lidar com os efeitos dos processos de racialização na nossa sociedade. Isto significa dizer que não trataremos a raça em quanto uma realidade ontológica, que determina o destino dos corpos (determinismo genético), nem patinaremos na disputa entre a sua factualidade ou ficcionalidade. É mais profícuo pensar a raça como efeito material de processos de racialização, o que supõe pensá-la no bojo das diversas formas de racismo.

A investigação genômica é caracterizada pelo momento tecnológico em que a biologia molecular é capaz de transformar dados biológicos em grandes mapas de dados informacionais, catalogados e armazenados em bancos de perfis genômicos, a partir de determinados marcadores e polimorfismos. Estes polimorfismos estão estatisticamente distribuídos entre diferentes populações, pensadas tanto em termos geográficos e cruzamentos genéticos que ocorrem em determinado lugar, quanto pelo que os geneticistas chamam de grupos ou populações parentais, que compartilham grande parte destes polimorfismos. Essas populações parentais são classificadas por categorias que remetem a noções de raça, origem geográfica, nacionalidade ou etnia, de modo que o contorno das fronteiras que se tenta estabelecer entre os diferentes grupos fica borrado por critérios pouco claros de classificação.

$\mathrm{Na}$ investigação em genética médica se buscam agrupar populações em estudos de caso e controle, nas quais se selecionam um conjunto de marcadores, dentre eles, os de raça, sexo, idade, dentre outros, dependendo do fenótipo que se busca investigar. O fenótipo é a expressão do genótipo, isto é, a forma como a combinação de genes que um indivíduo carrega se apresenta, seja na forma de caraterísticas físicas aparentes, como na fisiologia, como na manifestação ou não de doenças, etc. 


\section{Nanduty}

ISSN:2317-8590

Entretanto, conforme explicam os geneticistas, são poucos os genes implicados nos caracteres físicos aos quais associamos a raça (cerca de seis, num universo de 30 mil genes) e, não necessariamente estes genes são os mesmos implicados em determinadas suscetibilidades em processos de saúde/doença. Do mesmo modo, poucas são as doenças cuja causalidade seja explicada em termos monogênicos, isto é, relacionadas a apenas um gene. Desse modo, são mais raras as condições às quais se oferecem explicações como aquelas das chamadas midiáticas que afirmam que foi encontrado o gene para determinada condição -"encontrado o gene do Alzheimer". Antes, a expressão fenotípica de determinada condição está, na maior parte das vezes, associada à reunião de vários genes, sendo, portanto, condições poligênicas.

Diante desta complexidade, faria pouco sentido as investigações continuarem sendo conduzidas pautadas por classificações raciais, tendo em vista a baixa correlação genótipo/fenótipo, as controvérsias relacionadas à classificação racial já referidas e, ainda, considerando o desenvolvimento das investigações científicas, cada vez mais voltadas para uma medicina personalizada. Entretanto o que se observa é que investigações na genética médica e demais campos da medicina nunca deixaram de se dedicar ao recorte populacional por raças.

A posse desse tipo de informação fornecida pela biotecnologia e que mapeiam a vida em nível molecular atualizam as reflexões acerca do biopoder. Os dados populacionais são armazenados e partilhados por pesquisadores do mundo todo, sendo a classificação racial um dispositivo que se atualiza por diferentes caminhos.

Mesmo as pesquisas da biomedicina tentando purificar as categorias utilizadas de perturbações sociais e políticas, afirmando seu caráter estritamente metodológico, relacionando-as a modelos matemáticos e estatísticos, a triagem dos pacientes ainda é feita empregando critérios fenotípicos como cor da pele, tamanho dos lábios e nariz, textura do cabelo, etc, mesmo considerado que há baixa correlação desses caracteres fenotípicos com os caracteres genotípicos dos indivíduos.

Estes são os mesmos critérios empregados na heteroidentificação de candidatos ao ingresso por cotas nas universidades e concursos públicos. Nesses espaços, nega-se, por sua vez, que se esteja falando de raça em um sentido biológico e, argumenta-se, grosso modo, que quanto mais próximo ao fenótipo negro, mais desvantagem social um sujeito teria sofrido ao longo de sua vida, o que o torna elegível às políticas de ações afirmativas. 


\section{Nanduty}

ISSN:2317-8590

Diante das controvérsias e disputas que o tema das classificações tem colocado desde o mapeamento do genoma humano decidi aproximar-me do fazer dos geneticistas para verificar, em suas práticas, as estratégias de estabilização das quais lançavam mão para a materialização da categorização de populações, tendo em vista que em suas publicações estas questões apareciam de forma pacificada enquanto, no debate público, as classificações raciais com a finalidade de acesso às políticas públicas com recorte racial ainda pareciam muito controversas

Portanto, extrapolando o interesse original nas práticas e produções da ciência, fui rastreando conexões que foram me levando a outros espaços institucionais nos quais um saber científico sobre o corpo e suas especificidades raciais é acionado com vistas a responder demandas burocráticas, quais sejam, a elaboração de protocolos de procedimentos profissionais de como considerar a raça e o racismo na intervenção em saúde, a consideração dos chamados fatores de riscos, nos quais a raça figura como marcador para maior suscetibilidade e/ou agravo em saúde, o modo como a categoria tem sido lida nos dados epidemiológicos, na formulação e execução de políticas públicas voltadas para a saúde, nos procedimento de bancas de aferição de auto-declaração em concursos em que se buscam materialidades fenotípicas para a classificação dos candidatos, etc.

Esse caminho levou-me ao estudo dos processos de institucionalização da raça enquanto marcador importante para a formulação de políticas públicas, especialmente a partir da década de 1990, quando há o reconhecimento do estado brasileiro da existência do racismo no país, quando o Governo de Fernando Henrique Cardoso instituiu, no Ministério da Justiça, o Grupo de Trabalho Interministerial de Valorização da População Negra, com a incumbência de recomendar e promover políticas de "consolidação da cidadania da população negra", através do decreto presidencial de 20 de novembro de 1995, em resposta à mobilização ocorrida em Brasília, que reuniu mais de 30 mil pessoas (SILVA et al., 2009, p. 33).

A primeira década dos anos 2000, no Brasil, foi muito significativa para os movimentos identitários no país, particularmente, o movimento negro, quando houve a criação de várias instâncias governamentais para o enfrentamento ao racismo, haja vista que este expõe os sujeitos a diversos tipos de vulnerabilidade social, requerendo a intervenção do Estado com medidas voltadas para a garantia de equidade.

Para finalizar, gostaria de trazer o relato de dois interlocutores que tem uma relação controversa com a categoria raça em suas práticas, reconhecendo a pertinência e os 


\section{Nanduty}

ISSN:2317-8590

imperativos burocrático-institucionais de empregá-la, mas ao mesmo tempo evidenciando dilemas éticos, políticos e metodológico na sua utilização.

A primeira interlocutora é uma hematologista que trabalha com pacientes com doença falciforme e o segundo, um geneticista que trabalha com imunogenética. Em entrevista com estes profissionais, a hematologista, por um lado, discorreu sobre as razões pelas quais "a raça lhe atrapalha" devido, sobretudo, ao racismo institucional, mas também considerando que em determinados momentos de sua prática, a raça é um dado pertinente; por outro lado, o imunogeneticista se questionava sobre o eventual caráter racista do emprego de categorias raciais em seu trabalho, tendo em vista a importância médica de considerar as especificidades raciais em saúde.

Conforme a hematologista, as disputas em torno da regulamentação do transplante de medula óssea para tratamento de pacientes com doença falciforme, no âmbito do Sistema Único de Saúde (SUS), até então restrita aos pacientes leucêmicos com até 16 anos de idade, foi marcada pelo racismo institucional, tendo em vista a associação da doença falciforme à população negra. Segundo a hematologista havia uma resistência técnica, no Ministério da Saúde, quanto à ampliação da faixa etária dos pacientes que poderiam se submeter ao transplante no caso da anemia falciforme, tendo em vista que o protocolo de transplante de medula até então só admitia a idade máxima de 16 anos, considerando a sua eficácia. Entretanto, citando a literatura internacional ela afirmou que, nos casos de anemia falciforme, o transplante também funciona em pacientes mais velhos e a resistência do ministério foi entendida como um caso de racismo institucional, de modo que, para ela, atrelar a doença à raça, significava fechar portas.

Outra situação em que ela julgava que a raça atrapalha é na formação de novos médicos. Quando questionada sobre determinadas especificidades do leucograma de pacientes negros, como a baixa contagem de neutrófilos, ela afirmou que "nessa aula, esse slide era suprimido", pois o leucograma é um exame que traz importantes informações para o diagnóstico de doenças hematológicas graves e, que se essa informação for disseminada entre os alunos/futuros médicos nunca mais uma doença grave seria diagnosticada em um paciente negro, pois haverá a naturalização de que em pacientes negros a baixa contagem de alguns elementos do leucograma é normal, e, portanto, deixariam se ser melhor investigados.

Por fim, uma terceira situação relatada, que evidencia as controvérsias suscitadas pela raça em sua prática profissional foi aquela em que, participando de um round de necrópsia 


\section{Nanduty}

ISSN:2317-8590

(encontro de médicos para aventar a causa mortis de pacientes) ela levantou a mão e perguntou qual a raça do paciente, afirmando que se esta informação fosse posta de imediato, seria mais fácil chegar mais rapidamente a causa da morte do paciente.

A conversa com o imunogeneticista, por sua vez, foi na direção de uma reflexão sobre os problemas da classificação racial de pacientes para considerar suas especificidades no que diz respeito a suscetibilidades e resistência a condições patológicas. Defendendo a importância de separar pacientes em subgrupos, com vistas a lhes oportunizar um tratamento mais adequado, o pesquisador trouxe o exemplo da sua investigação sobre lúpus:

assim como a foto-sensibilidade era mais comum entre paciente lúpico caucasóide, a nefrite é mais comum entre o paciente lúpico de origem afro-descendente. Se eu pegar e analisar todos de uma única maneira, todos os pacientes lúpicos junto, eu não vou ver isso daí. Eu vou dizer que existe nefrite e existe foto-sensibilidade. Agora eu sei que a foto-sensibilidade tá num subgrupo desses pacientes e a nefrite tá em outro subgrupo. Se eu analisar de maneira subgrupada, fazendo subgrupos, eu vou ter que, de repente, dar um tratamento mais adequado pro paciente, porque eu sei que ele tem maior suscetibilidade pra uma coisa ou outra, então nesse caso, a pergunta: vale a pena eu fazer subgrupos? Ao fazer subgrupos eu estou dando uma informação a mais pra ajudar meu paciente? Eu acredito que sim, né? E é por isso que a gente termina fazendo a análise, subgrupando por origem étnica. Agora a pergunta é a seguinte: como fazer isso dentro de uma população como a nossa que é miscigenada? E aí entra o nosso grande problema, né?

Dessa breve referência aos diferentes momentos em que a médica diz que raça atrapalha sua prática profissional podemos extrair pelo menos três versões de raça, ou seja, três maneiras pelas quais raça é performada (enacted) (MOL, 2008) no âmbito de um mesmo saber - o saber médico -, porém, em distintos processos de interações: a raça, que atrelada à especificidade racial de uma doença genética, no contexto das disputas em torno da regulamentação do transplante, dificultou as negociações; a raça silenciada como categoria que levaria à negligência no diagnóstico pelos futuros médicos; a raça silenciada pela interdição do emprego da categoria na área médica, mas reivindicada para facilitar a definição da causa mortis do paciente.

O que a narrativa da médica sugere é que raça é dotada de uma existência ontológica, subjacente e encoberta por práticas específicas e cujo desvelamento se dá conforme o juízo e decisão daqueles, que como ela, operacionaliza conforme pertinente, de um ponto de vista técnico - evidenciando com a finalidade de fechamento de um diagnóstico, ou omitindo-a 


\section{Nanduty}

ISSN:2317-8590

quando for um fator de confusão (ou negligência decorrente da naturalização) - ou conveniente, de um ponto de vista político.

A forma como raça é praticada, no bojo das decisões de quem a performa, inscreve a categoria em uma "política ontológica" (MOL, 2007), fundamentando-a naquilo que John Law e AnneMarie Mol (2004) chamaram de materialismo relacional, segundo o qual os objetos são conjuntos de efeitos relacionais, mais ou menos precários, no sentido de que não se pode dizer que eles existam por si mesmos. Os materiais não existem para além de suas interações, que são transitórias, são efeitos.

O imbricamento das práticas de investigação científica de médicos e geneticistas com demandas colocadas por uma comunidade científica aparentemente externa ao seu fazer, mas para a qual eles contribuem e se retroalimentam, bem como suas respostas institucionais a instâncias do estado que financiam suas investigações, ao mesmo tempo que regulam e gestam as práticas de saúde me levaram a participar de outros espações institucionais ligados à saúde no intuito de me apropriar sobre as maneiras pelas quais a raça tem se materializado também nestes espaços, nos quais decisões burocráticas são tomadas a partir da interseção de saberes produzidos pela ciência, pelos movimentos sociais e pela gestão burocrática da saúde, a partir de grupos de trabalho do ministério da saúde e secretarias especiais, voltadas para a especificidade racial em saúde.

O trânsito entre estes diferentes domínios evidenciam a concomitante produção de diferentes versões de raça por diferentes agencias, quais sejam, as diferentes instâncias da ciência, do estado e dos movimentos sociais, materializando a raça por meio de diferentes mediações, seja o emprego de banco de perfil genômico organizado por categorias populacionais racializadas por geneticistas, o emprego do quesito raça-cor em cadastros e prontuários médicos, taxas de referências de exames laboratoriais, prescrições de medicamentos pautados por raça, políticas públicas com recorte racial em saúde firmados em portarias ministeriais, etc.

Essas mediações revelam que a raça, a despeito de sua existência ontológica, ganha corpo em materialidades institucionais que orientam o fazer e as decisões de cientistas, profissionais e gestores da saúde, movimentos sociais, estando presente na formulação de políticas públicas, na regulação de procedimentos de intervenção em saúde, respondendo às demandas dos movimentos sociais pelo atendimento de suas especificidades, mas também 


\section{Nanduty}

ISSN:2317-8590

oferecendo um ordenamento burocrático às práticas do estado, garantindo legibilidade às populações para as quais direcionam suas políticas e subsidiando a governança.

\section{CONSIDERAÇÕES FINAIS}

Pensar a raça em conjunto com os interlocutores da genética e da biomedicina tem desafiado o modo como temos pensado separadamente até aqui: como uma categoria que vacila entre campos semânticos irreconciliáveis, porque de um lado se preconiza o que é dado e do outro o que é representado ou discursivo. Os estudos sociais da ciência e tecnologia têm me ajudado a pensar a materialidade dos objetos e, portanto, a raça, para além do que supostamente estaria dado na natureza, para pensá-la como efeito de práticas e discursos. Nesse sentido, rompe-se com a separação entre referente e significado para se pensar em efeito material-semiótico. Nessa chave analítica, a raça não existiria somente de modo dado $a$ priori, nem seria apenas um constructo social, discursivo, com finalidades políticas, mas efeito material-semiótico (HARAWAY, 1995) de práticas que a produzem e lhe conferem materialidade.

Esta materialidade seria relacional, nos termos de Mol e Law (1994), na medida em que o modo como raça aparece e evanesce em determinados contextos é fruto das articulações de dispositivos, mediadores e discursos que se mostrem pertinentes a respostas e decisões institucionais que se pretendem quando diferentes relações de força e disputas estão em jogo.

Nessa perspectiva não há como negligenciar os efeitos do racismo institucional no modo como a raça materializada no cotidiano das práticas da ciência, mas também de instâncias de decisão do estado e mesmo nas articulações de contestação dos movimentos sociais, quando diferentes formas se materialização da raça tomam corpo.

A demanda pela raça e seus desdobramentos apareceram reiteradas vezes nos relatos dos meus interlocutores da genética e da medicina que afirmavam que, por diferentes caminhos o emprego da raça se impunha em suas práticas, desde requisito para a publicação de artigos científicos, como na relação com instâncias governamentais ligadas à gestão da saúde pública. Entretanto dependendo da finalidade do estudo ou do público para o qual se reportam, o aspecto racial de seus trabalhos são demonstrados ou não.

No bojo desta reflexão tenho buscado fazer, portanto, um exercício analítico de compreender como uma "infraestrutura de racialização" tem sido articulada por diferentes 


\section{Nanduty}

ISSN:2317-8590

demandas institucional-burocráticas de intervenção no corpo e na saúde da população negra no Brasil, de modo a evidenciar diferentes estratégias biopolíticas que apesar de bem intencionadas podem aqui e ali resvalar para a naturalização das diferenças e das desigualdades.

O "fazer morrer" (FOUCAULT, 1975; 1977) se materializa em práticas nas quais se negligencia especificidades em saúde em nome da universalidade que preconiza uma igualdade de direitos que não se verifica de fato. A noção de racismo institucional, que subjaz toda esta reflexão, tem sido empregada por críticos das ciências humanas e sociais, bem como pelos movimentos sociais para se referir a certos "descuidos" das instituições, que não são expressamente racistas, mas que ao lançarem mão de dispositivos como a "ignorância estratégica", invisibilizam certas demandas de populações que podem custar sua vida material e simbólica. 


\section{REFERÊNCIAS}

\section{ABE-SANDES, K.; BONFIM, T. F.; MACHADO, T. M. Ancestralidade Genômica,} nível socioeconômico e vulnerabilidade ao HIV/aids na Bahia. Saúde e Sociedade.

Vol. 19 Sup. 2. Dez, 2010. Disponível em: http://bvsms.saude.gov.br/bvs/periodicos/saude_sociedade_19_supl2.pdf Acesso em 30 Mai 2019.

ANDERSON, Benedict R. Comunidades imaginadas: reflexões sobre a origem e a difusão do nacionalismo. São Paulo: Companhia das letras, 2008.

BORTOLINI, Maria Cátira. Resposta ao trabalho de Kent e Santos: "'Os charruas vivem' nos Gaúchos: a vida social de uma pesquisa de 'resgate' genético de uma etnia indígena extinta no Sul do Brasil". Horiz. antropol., Porto Alegre, v. 18, n. 37, p. 373-378, June 2012 . Available from $\quad<$ http://www.scielo.br/scielo.php?script=sci_arttext\&pid=S010471832012000100016\&lng=en\&nrm=iso>. Acesso: 01 Jun 2019.

CORREA P.B; TORALLES, M.B; ABE-SANDES, K; MACHADO, T. M.; BONFIM. Câncer de mama triplo negativo e sua associação com ancestralidade africana. Revista de Ciências Médicas e Biológicas. Vol. 9. 2010. Disponível em: <https://portalseer.ufba.br/index.php/cmbio/article/view/4631/3498> Acesso 30 Mai 2019.

COSTA, Rosely Gomes. Doação de sêmen e classificação étnico-racial no Brasil, In: SANTOS, Ricardo Ventrua, GIBBON, Sahra e BELTRÃO, Jane (Orgs.). Identidades emergentes, genética e saúde: perspectivas antropólogicas. Rio de Janeiro: Garamond; Rio de Janeiro: Fiocruz, 2012. pp. 95-109.

FOUCAULT, M. Em defesa da sociedade: curso no College de France (1975-1976). São Paulo: Martins Fontes, 1999.

FOUCAULT, M. História da Sexualidade I: a vontade de saher. Trad. M.T. C. Albuquerque e J. A G. Albuquerque. Rio de Janeiro: Graal, 1977b.

FOUCAULT, M. Microfísica do Poder. Organização e introdução de Roberto Machado. 3.ed. Rio de Janeiro: Graal, 1982.

GIBBON, Sahra; NOVAS, Carlos. Genetics and Social Sciences. In: Biossocialities, Genctics and Social Sciences: making biology and identities. Routledge: USA e Canadá: 2008. pp. 1-18.

GILROY, Paul. Entre campos: nações cultura e o fascínio da raça. São Paulo: Annablume: 2007.

GONZALES, Elena Calvo. 'Neutrófilo baixo quer dizer pé na cozinha?': o papel de cientistas e não-cientistas nos discursos sobre leucopenia e diferença "racial" no Brasil contemporâneo. $33^{\mathrm{a}}$ ANPOCS, 2009. Anais.

HARAWAY, Donna. Saberes localizados: a questão da ciência para o feminismo e o privilégio da perspectiva parcial. Campinas, Cadernos Pagu, n. 5, 1995, p.7-41.

LAW, John; MOL, Annemarie. Notas sobre el materialismo. Politica y Sociedad, Madrid v. 14, n. 15, 1993-1994, p. 47-57.

POUTIGNAT, Philippe. Teorias da Etnicidade. Seguido de Grupos étnicos e susas fronteiras de Fredrik Barth / Philipe Poutignat, Jocelyne Streiff-Fenart; tradução de Elcio Fernandes. São Paulo: Fundação Editora da UNESP, 1998.

LEE, Sandra Soo-Jin. Racializing Drug Design: implications of Pharmacogenomics for health disparities. American Journal of Public Health, 95(12), 2133-8. 2005. 
PENA, S.D.; BORTOLINI, M. C. Pode a genética definir quem deve se beneficiar das cotas universitárias e demais ações afirmativas? Estudos Avançados, v. 18, n. 50, p. 31-50. Universidade de São Paulo: 2004.

KENT, Michael.A importância de ser Uro: moviementos indígenas, políticas de identidade e pesquisa genética nos Andes peruanos. In: SANTOS, Ricardo Ventrua, GIBBON, Sahra e BELTRÃO, Jane (Orgs.). Identidades emergentes, genética e saúde: perspectivas antropólogicas. Rio de Janeiro: Garamond; Rio de Janeiro: Fiocruz, 2012. pp. 201-232.

KENT, Michael; SANTOS, Ricardo Ventura. "Os charruas vivem" nos Gaúchos: a vida social de uma pesquisa de "resgate" genético de uma etnia indígena extinta no Sul do Brasil. Horiz. antropol., Porto Alegre, v. 18, n. 37, p. 341-372, June 2012 . Available from $<$ http://www.scielo.br/scielo.php?script=sci_arttext\&pid=S0104-

$71832012000100015 \& \operatorname{lng}=\mathrm{en} \& n \mathrm{~m}=\mathrm{iso}>$. Acesso 01 Jun 2019.

M'CHAREK, Amade. Beyond Fact or Fiction: On the Materiality of Race in Practice. Cultural Anthropology, v. 28, n. 3, 2013, p. 420-442.

Fragile Differences, Relational Effects. Stories about the materiality of race and sex. European Journal of Woman's Studies, v. 17, n. 4, 2010, p. 1-16.

Race, Time and Folded Objects: The HeLa Error. Theory, Culture \& Society, v. 31, n. 6, 2014, p. 29-56.

MOL, Annemarie. Política Ontológica. Algumas ideias e várias perguntas. In: JÚNIOR, Nunes; ROQUE, R. (Org.). Objetos Impuros: Experiências em Estudos sobre a Ciência. Porto: Edições Afrontamento, 2008, p. 63-77.

OLIVEIRA, Fátima. Singularidades. In: Saúde da População Negra: Brasil ano 2001. Brasíla:Organização Pan-Americana da Saúde, 2003. 342p.

PENA, Sérgio D. J. Para remover a palavra raça dos prontuários médicos no Brasil. Ciência e Cultura. Tendências, v. 59, n.1, pp. 4-5, jan-mar. 2007.

PENA, Sérgio D. J. Razões para banir o conceiro de raça da medicina brasileira.

História, Ciênicias, Saúde - Manguinhos, v. 12, n. 1, pp. 321-46, maio-ago. 2005.

; Bortolini, M. C. Pode a genética definir quem deve se beneficiar das cotas universitárias e demais ações afirmativas? Estudos Avançados, v. 18, n. 50, p. 31-50. Universidade de São Paulo: 2004.

SCHWARCZ, Lilia Moritz. O Espetáculo das Raças. São Paulo: Companhia das Letras, 1993.

SCHWARCZ, Lilia Moritz. As teorias raciais, uma construção histórica de finais do século $X I X$. O contexto brasileiro. In: e Diversidade. Estação Ciência/Edusp: São Paulo, 1996.

SILVA, Adailton; Luiz, Crisitana; Jaccoud, Luciana; Silva, Waldemir. Entre o racismo e a desigualdade: da constituição à promoção de uma política de igualdade racial (1988-2008) In:

A Promoção de uma política de Igualdade Racial: uma análise dos últimos 20 anos. Luciana Jaccoud (org.). Brasília: Ipea, 2009. 19-92.

SILVA, Mozart Linhares da. Miscigenação e Biopolítica no Brasil1. Revista Brasileira de História \& Ciências Sociais. Vol. $4 \mathrm{~N}^{\mathrm{o}}$ 8, Dezembro de 2012. Disponível em: http://www.rbhcs.com/index_arquivos/Artigo.MiscigenacaoeBiopoliticanoBrasil.pdf.

UNESCO. Declaração sobre a raça e os preconceitos raciais (1978). Disponível em: $<$ http://www.direitoshumanos.usp.br/index.php/UNESCO-Organiza\%C3\%A7\%C3\%A3odas-Na\%C3\%A7\%C3\%B5es-Unidas-para-a-Educa\%C3\%A7\%C3\%A3o-Ci\%C3\%AAncia-eCultura/declaracao-sobre-a-raca-e-os-preconceitos-raciais.html> Acesso 01 Jun 2019. 


\section{Nanduty}

ISSN:2317-8590

VILLAR, Diego. Uma Abordagem Crítica do Conceito de "Etnicidade" na Obra de Fredrik Barth. MANA 10 (1): pp. 165-192. 2004. 